\title{
BINA SUASANA SEBAGAI UPAYA PENCEGAHAN PENYALAHGUNAAN NARKOBA DI SMA SEDERAJAT KOTA SURABAYA
}

\section{Effort To Prevent Drug Abuse in The Surabaya High School Equivalent}

\author{
Jeni Martiyanti Fitriana \\ Departemen Promosi Kesehatan dan Ilmu Perilaku, Fakultas Kesehatan Masyarakat, \\ Universitas Airlangga \\ email: jennifitriana@gmail.com
}

\begin{abstract}
The high rate of drug abuse in Indonesia has spread to high school adolescents. 183 million people consume marijuana, 35 million opioids, 37 million amphetamines and drug stimuli, 22 million ecstasy, 18 million opiates, 17 million kokai (BNN, 2017). East Java is one of the provinces where the population is at risk of experiencing drug abuse. Surabaya occupies a position as a metrapolitan city which has a high level of modernity both from technology and infrastructure. The high level of population and technological advances have made this region vulnerable to drug abuse. The role of the School is to develop capabilities and shape dignified national character and civilization in order to educate the life of the nation and the state aimed at developing potential students to become human beings who believe and fear God Almighty, noble, healthy, knowledgeable, capable, creative, be independent, and become a democratic and responsible citizen. For this reason, schools have an important role related to the prevention of drug abuse. Based on the data and policies obtained, the researchers aimed to identify the atmosphere development strategy in schools in an effort to prevent drug abuse in schools. This research was conducted using in-depth interviews with 14 informants who held positions as teachers. The research conducted will later use the WHO 1984 Health Promotion Strategy approach by using atmosphere development variables. The results of the study stated that the community development activities carried out in North Surabaya's high schools were in the form of peer counselors, teaching and learning activities, inspection, urine tests and counseling facilities.
\end{abstract}

Keywords: Health Promotion Strategy, Community Development, Drug Prevention

\begin{abstract}
Abstrak
Tingginya angka penyalahgunaan narkoba yang terjadi di Indonesia merebak pada siswa remaja berstatus sekolah menengah atas. Sebanyak 183 juta orang mengonsumsi ganja, 35 juta orang opioid, 37 juta orang amfetamin dan obat rangsangan, 22 juta orang ekstasi, 18 juta orang opiat, 17 juta orang kokai (BNN,2017). Jawa Timur merupakan salah satu provinsi yang penduduknya berisiko mengalami penyalahgunaan narkoba. Surabaya merupakan kota metrapolitan yang mana memiliki tingkat kemodernan yang tinggi baik dari teknologi maupun infrastruktur. Banyaknya tingkat penduduk dan kemajuan teknologi ini menyebabkan wilayah ini rentan terhadap penyalahgunaan Narkoba. Peranan Sekolah yaitu berperan mengembangkan kemampuan dan membentuk watak serta peradaban bangsa yang bermartabat dalam rangka mencerdaskan kehidupan bangsa dan negara bertujuan untuk berkembangnya potensi peserta didik agar menjadi manusia yang beriman dan bertakwa kepada Tuhan Yang Maha Esa, berakhlak mulia, sehat, berilmu, cakap, kreatif, mandiri, dan menjadi warga negara yang demokratis serta bertanggung jawab. Untuk itu sekolah memiliki peranan yang penting terkait dengan pencegahan penyalahgunaan narkoba. Berdasarkan data dan kebijakan yang didapat, peneliti bertujuan untuk melakukan identifikasi strategi bina suasana di sekolah dalam upaya pencegahan penyalahgunaan narkoba di sekolah. Penelitian ini dilakukan dengan metode wawancara mendalam kepada 14 informan yang memiliki jabatan sebagai guru. Penelitian yang dilakukan nantinya akan menggunakan pendekatan Strategi Promosi Kesehatan WHO 1984 dengan menggunakan variabel bina suasana. Hasil penelitian menyatakan kegiatan bina suasana yang dilakukan di Sekolah Menengah
\end{abstract}


Atas Surabaya Utara berupa adanya konselor sebaya, Kegiatan belajar mengajar, sidak , tes urin dan fasilitas Guru BK.

Kata kunci: strategi promosi kesehatan, bina suasana, pencegahan narkoba

\section{PENDAHULUAN}

Survei yang dilakukan diberbagai negara menunjukkan kecenderungan peningkatan penyalahgunaan narkoba antara tahun 20062015. Hasil survei juga menunjukkan sebanyak 183 juta orang mengonsumsi ganja, 35 juta orang opioid, 37 juta orang amfetamin dan obat rangsangan, 22 juta orang ekstasi, 18 juta orang opiat, 17 juta orang kokain (UNODC, 2017). Perkiraan pengguna narkoba ini memiliki kriteria dewasa dengan golongan usia antara 1564 tahun dalam setahun terakhir. Diantara pengguna napza tersebut, 1,6 juta orang hidup dengan HIV, 6,1 juta hidup dengan Hepatitis C, dan sebanyak 1,3 juta hidup dengan HIV dan hepatitis C (UNODC, 2017).

Berbeda dengan hasil survei yang dilakukan di indonesia, kecenderungan angka prevalensi penyalahgunaan narkoba menunjukkan penurunan mulai dari tahun 20062016. Kejadian penyalahgunaan narkoba terbagi menjadi dua periode waktu yaitu pernah pakai dan pakai setahun terakhir, namun pada keduanya sama-sama mengalami penurunan. Pada kasus pernah pakai penyalahgunaan narkoba mencapai $8,1 \%$ dan mengalami penurunan ditiap tahun hingga pada tahun 2016 menjadi 3,8\%. Sama halnya dengan kasus pakai setahun terakhir, angka prevalensi penyalahgunaan narkoba mencapai $5,2 \%$ di tahun 2006 dan mengalami penurunan tiap tahun, hingga pada tahun 2016 menjadi 1,9\% (BNN, 2016).

Berdasarkan hasil survei Badan Narkotika Nasional pelaku penyalahgunaan narkoba laki-laki lebih besar dibandingkan dengan perempuan, namun pelaku penyalahgunaan narkoba juga mengalami penurunan mulai tahun 2006 hingga 2016 (BNN, 2016). Pada jenis kelamin laki-laki pada tahun 2006 sebanyak 13,7\% dan mengalami penurunan di tahun 2016 sebanyak 6,4\%. Pada perempuan di tahun 2006 sebanyak 3,37\% dan menurun di tahun 2016 sebanyak 1,6\%. Di tahun 2016, pada periode waktu pernah pakai, pemakai pada pelajar tingkat Menengah Atas dan Perguruan Tinggi memiliki persentase yang sama yaitu sebanyak $4,3 \%$, sedangkan pada periode waktu pakai setahun terakhir, pemakai pada tingkat pelajar Menengah Atas lebih tinggi dibanding dengan pelajar Perguruan Tinggi. Data menunjukkan pelajar tingkat Menengah Atas mencapai $2,4 \%$ dan pada Perguruan Tinggi mencapai 1,7\% (BNN, 2016).

Jawa Timur merupakan salah satu provinsi yang penduduknya berisiko mengalami penyalahgunaan narkoba. Prevalensi penyalahgunaan narkoba yang terjadi Provinsi Jawa timur pada tahun 2017 sebanyak 492,157 jiwa. Namun, penyalahgunaan di Provinsi Jawa Timur mengalami penurunan dari tahun 2014 2017. Tahun 2014 penyalahgunaan narkoba di Jawa Timur sebanyak 1,99\% dan mengalami penurunan di tahun 2017 menjadi 1,72\%. Hal ini mengakibatkan Jawa Timur mengalami kerugian sosial ekonomi yang besar kedua setelah kerugian yang terjadi di Jawa Barat (BNN, 2017).

Menurut Badan Pusat Statistik, Surabaya merupakan ibu kota provinsi Jawa Timur dengan jumlah penduduk terbanyak kedua setelah Jakarta yaitu sejumlah 2,765 juta penduduk (BPS, 2017). Surabaya menempati kedudukan sebagai kota metrapolitan yang mana memiliki tingkat kemodernan yang tinggi baik dari teknologi maupun infrastruktur. Banyaknya tingkat penduduk dan kemajuan teknologi ini menyebabkan wilayah ini rentan terhadap penyalahgunaan narkoba. Berdasarkan pada Perwali nomor 65 tahun 2014 tentang rencana Aksi Pelaksanaan Kebijakan dan Strategi Daerah Bidang Pencegahan, Pemberantasan Penyalahgunaan dan Peredaran Gelap Narkoba Kota Surabaya Tahun 20142015 dicantumkan bahwa salah satu sasaran dalam program pencegahan narkoba adalah siswa SMP dan SMA. Menurut KBBI, definisi siswa itu sendiri merupakan seorang pelajar yang berada dalam wadah naungan sekolah. Menurut Undang-Undang Republik Indonesia Nomor 20 tahun 2003, pada Bab 2 Pasal 3 tentang dasar, fungsi dan tujuan dimana didalamnya memuat tentang Peranan Sekolah yaitu berperan mengembangkan kemampuan dan membentuk watak serta peradaban bangsa yang bermartabat dalam rangka mencerdaskan kehidupan bangsa dan negara bertujuan untuk berkembangnya potensi peserta didik agar menjadi manusia yang beriman dan bertakwa kepada Tuhan Yang Maha Esa, berakhlak 
mulia, sehat, berilmu, cakap, kreatif, mandiri, dan menjadi warga negara yang demokratis serta bertanggung jawab. Untuk itu sekolah memiliki peranan yang penting terkait dengan pencegahan penyalahgunaan narkoba.

Berdasarkan data dan kebijakan yang didapat, penelitian ini bertujuan untuk melakukan identifikasi strategi sekolah dalam upaya pencegahan penyalahgunaan narkoba. Penelitian yang dilakukan nantinya akan menggunakan pendekatan Strategi Promosi Kesehatan WHO 1984 dengan menggunakan variabel Bina Suasana. Variabel yang terdapat dalam strategi promosi kesehatan WHO ini sesuai dengan variabel yang akan diteliti. Sasaran dalam penelitian ini adalah SMA sedarajat yang berada di wilayah Surabaya. Dengan mengetahui strategi Bina Suasana yang digunakan dalam sekolah tersebut diharapkan dapat dijadikan sebagai acuan peningkatan program pencegahan penyalahgunaan narkoba, khususnya di Kota Surabaya.

\section{METODE PENELITIAN}

Jenis penelitian yang digunakan dalam penelitian ini adalah penelitian deskriptif dengan pendekatan kualitatif menggunakan teknik wawancara mendalam. Kegiatan wawancara dilakukan pada 20 Agustus 2018 18 September 2018. Kegiatan wawancara ini dilakukan kepada 14 informan berupa Guru. Pertanyaan yang digunakan dalam kegiatan wawancara mencakup yang pertama, kegiatan apa saja yang dilakukan oleh sekolah terkait pencegaha penyalahgunaan narkoba, siapa yang terlibat dan bagaimana pelaksanaanya. Hasil wawancara yang didapat di analisis secara kualitatif dan diuraikan secara deskriptif. Dalam penelitian deskriptif digunakan untuk melihat dan mendeskripsikan fakta, keadaan, fenomena, variabel dan keadaan yang sedang terjadi saat dilakukannya penelitian. Sehingga dalam proses pengambilan informasi, seorang peneliti harus menuliskam secara asli, sesuai realita tanpa ada tambahan apapun dan tidak memanipulasi.

\section{HASIL DAN PEMBAHASAN}

Kegiatan Bina Suasana adalah terciptanya kondisi lingkungan yang mendukung pencegahan di sekolah menengah atas. Aspek yang ditinjau dalam penelitian ini adalah adanya kegiatan lomba terkait narkoba, media narkoba, konselor sebaya, peran BK, dan juga kegiatan lainnya yang mendukung.

\section{Konselor Sebaya}

Hasil yang didapat dari 10 guru perempuan yang merupakan informan utama, di lokasi penelitian adalah adanya peer konselor atau teman sebaya. Hal ini dijelaskan oleh informan dengan keterangan sebagai berikut

"...Kalau dulu itu sebelum ikut provinsi dinas pendidikan itu ada kok konselor sebaya, anak-anak itu dipilih per kelas yang mau dan yang bisa komunikasi(IU,03)"

Selain memberi edukasi, konselor sebaya ini nantinya juga diarahkan untuk memahami permasalahan teman-temannya dan dapat mengatasi masalah tersebut, dan dibantu BK dalam pekerjaannya. Hal ini dijelaskan oleh informan dengan keterangan sebagai berikut

"...setelah pelatihan saya kumpulkan lagi. Nah sekarang kita coba untuk terjun di lapangan saya bilang gitu. Itu langsung di laksanakan. Besoknya sudah laporan. Bu saya udah dapet bu, saya udah dapet dua klien $(I U, 04)^{\prime \prime}$

Hal ini juga disampaikan oleh informan saat melakukan wawancara dengan narasumber dari konselor sebaya. Informan menjelaskan bahwa peran sebagai konselor memantau kondisi temannya dan sebagai wadah curhat serta merangkul teman-temannya yang bermasalah. Hal ini disampaikan dengan keterangan sebagai berikut

"Kalau yang tugasnya itu lebih kayak memantau anak-anak (IK,04")

"...Jadi kayak lebih merangkul temen-temen yang sekiranya diem(IK,04)"

"Untuk kita curhat bisa, menyelesaikan masalah mencari jalan keluar.(IK,01)"

Selain teman sebaya, salah satu sekolah di lokasi penelitian juga membentuk Duta Narkoba. Kegiatan Duta Narkoba ini dibentuk karena adanya kegiatan kemitraan dengan kepolisian berupa lomba duta anti narkoba. Duta Narkoba dan tutor sebaya dianggap berbeda. Hal ini disampaikan informan dengan keterangan sebagai berikut

"Ada, pernah dilakukan. Jadi ada duta narkoba yang mengadakan pihak kepolisian jadi kita mengikutsertakan siswa kami ke situ(IU,01)"

"...kalau duta narkoba kan dia hanya kusus untuk mensosialisasi dan mengedukasi ke 
teman-temannya tapi kalau tutor sebaya lebih luas. Kalau tutor sebaya per kelas ada kalau yang duta narkoba hanya dua orang pa 1 pi 1(IU,01)"

Adanya Kegiatan Bina Suasana ini sesuai dengan Perwali nomor 65 tahun 2014 tentang Rencana Aksi Pelaksanaan Kebijakan dan Strategi Daerah Bidang Pencegahan, Pemberantasan Penyalahgunaan dan Peredaran Gelap Narkoba Kota Surabaya Tahun 20142015. Salah satu kegiatan yang dilakukan dalam upaya pencegahan penyalahgunaan napza adalah berbentuk bina suasana yaitu pembentukan kader atau teman sebaya bagi siswa SMP dan SMA.

Berdasarkan hasil penelitian yang dilakukan sebelumnya, Terbentuknya Kader bentukan BNN Kota Surabaya berbasis Pelajar memberikan dampak positif bagi siswa. Kegiatan tersebut dapat dijadikan sebagai pengalaman hidup, pengembangan keterampilan sosial, menambah pengetahuan pelajar sehingga akan berdampak positif bagi kader sekolah yang bersangkutan. Dengan terbentuknya kader melalui $\mathrm{BNN}$, ia dapat dijadikan sebagai role model dan menyampaikan alasan untuk tidak menggunakan dan menghindari penggunaan narkoba (Sari, 2017). Hal ini sesuai dengan kejadian di beberapa lokasi penelitian di sekolah SMA sederajat Kota Surabaya yaitu Terdapat beberapa cara bagi mereka untuk menyampaikan materi tersebut. Ada yang dilakukan dengan sebatas mengobrol sharing sesama teman, namun ada pula yang masuk ke kelas-kelas untuk memberikan atau menyampaikan materi atau goes to class.

Adanya program peer educator atau konselor sebaya ini berperan sebagai wadah curhat bagi teman-temannya, membantu menemukan kasus dan membantu merangkul teman-teman yang dianggap bermasalah. Hal ini sesuai dengan penelitian yang dilakukan sebelumnya yang menyatakan Peran teman sebaya antara lain memberikan dukungan terhadap siswa, baik dukungan yang bersifat sosial, moral, dan emosional, mengajarkan berbagai ketrampilan sosial,seperti kerjasama, kemampuan berinteraksi, mengontrol diri, dan memecahkan masalah,menjadi agen sosialisasi bagi siswa, dan menjadi model atau contoh berperilaku bagi siswa lain (Kurniawan dan Sudrajat, 2017).

2. Sidak Narkoba dan Tes Urin
Selain kegiatan Duta narkoba dan Tutor Sebaya, di beberapa sekolah menengah atas di lokasi penelitian, 8 informa guru wanita sebagai informan utama menyatakan juga pernah dilakukan sidak. Sidak ini dilakukan oleh BNN. Puskesmas juga mengadakan tes urin. Hal ini dijelaskan oleh informan dengan keterangan sebagai berikut

"Sidak itu mereka masuk kekelas masingmasing untuk melihat barang bawaan apa yang dibawa siswa entah itu ada obat yang mengandung napza atau barang yang dibawa apa kita juga tidak tahu siswa, untuk itu mengadakan sidak secara berkala(IU,01)"

"Kadang mereka (Puskesmas) mengadakan tes urin untuk mereka kenak narkoba atau $\operatorname{tidak}(I U, 01) "$

Kegiatan tes urin disekolah ternyata juga pernah dilakukan oleh pihak kepolisian. Hal ini disampaikan oleh informan dengan keterangan sebagai berikut

"Iya pernah juga diminta ke sekolah untuk tes urin maupun penyuluhan(IU,07)"

Bina Suasana adalah suatu upaya yang difokuskan untuk menciptakan perilaku hidup sehat yang diperkenankan di masyarakat. Seorang akan merasa mau melakukan perilaku yang diperkenankan jika di suatu lingkungan ia berada terdapat beberapa orang yang memiliiki sejalan fikiran tentang opini perubahan perilaku yang disarankan tersebut. Sama halnya dengan di sekolah seorang akan merasa perilaku perubahan yng dilakukan tepat jika didukung dengan kegiatan yang mendukung kegiatan pencegahan narkoba seperti sidak dan tes urin (Kemenkes, 2011).

Adanya kerjasama dengan pihak lan seperti kepolisian dan BNN dalam kegiatan sidak sesuai dengan penelitian yang dilakukan sebelumnya, menyatakan bahwa keberhasilan kegiatan bina suasana didasarkan pada manfaat kemitraan (Kurniawan, 2018). Sama halnya dengan kegiatan bina suasana dalam pencegahan penyalahgunaan narkoba yaitu dengan terbentuknya bina suasana berupa peer edukator atau teman sebaya atau konselor sebaya karena adanya kerja sama dengan pemerintah Kota Surabaya, Dinas Pendidikan, maupun BNN kota Surabaya.

3. Fasilitas BK

Seluruh informan utama dengan jumlah 14 guru perempuan menyampaikan Peran BK 
juga sangat mendukung dalam menciptakan lingkungan berbasis pencegahan narkoba. Karena peran BK sendiri adalah wadah bagi siswa dalam menyampaikan keluh kesah maupun permasalahan siswa yang sedang dihadapi. Hal ini disampaikan informan dengan keterangan sebagai berikut

"..kalau ada kendala program atau apa kami kesana (BK). Untuk kita curhat bisa, menyelesaikan masalah mencari jalan keluar $(I K, 01) "$

Selain itu peran BK juga dapat digunakan untuk memfasilitasi siswa yang bermasalah tentang narkoba baik pengedar maupun pengguna. Hal ini disampaikan informan dengan keterangan sebagai berikut

"BK untuk memfasilitasi murd-murid, namanya juga guru yang difasilitsi ya murid-murid. Murid yang mnjadi korban guru ini bisa membawa siswa ke balai rehab bukan untuk diadili karena tidak puunya hak dan kewenangan disana supaya memudahkan, mendekatkan orang yang tadi gamungkin menjadi mungkin(IU,08)"

Adanya keterbukaan dari Guru BK adalah langkah yang mendorong untuk menciptakan kondisi yang mendukung perilaku kesehatan. Dengan adanya keterbukaan BK akan membantu menemukan kasus dan membantu dalam penemuan permasalahan remaja. Hal ini Sejalan dengan penelitian yang dilakukan oleh peneliti sebelumnya yang menyatakan sikap petugas kesehatan di fasilitas pelayanan kesehatan memengaruhi frekuensi kunjungan pasien (Rachmawati, 2017).

Penelitian ini sejalan dengan yang disampaikan oleh peneliti lain yang menyatakan petugas kesehatan yang memiliki sikap baik akan mendorong seorang pasien untuk datang ke petugas kesehatan dan melakukan perilaku yang diharapkan (Rachmawati, 2017). Begitu juga dengan sikap petugas sekolah yang berakaitan dengan pencegahan narkoba. Jika petugas memiliki sikap keterbukaan dan responsif maka akan mempermudah siswa untuk berkonsultasi dengan guru sehingga akan mendukung dalam melakuan perilaku pencegahan narkoba yang diharapkan.

4. Kegiatan belajar mengajar di sekolah

Sejumlah 5 informan dari 14 informan guru perempuan sebagai informan utama juga menyatakan Kegiatan Bina Suasana juga didukung dengan lomba poster tentang narkoba.
Poster ini nantinya ditempel di kawasan sekolah. Hal ini disampaikan oleh informan dengan keterangan sebagai berikut

"anak-anak OSIS sering mengadakan lomba poster gitu jadi temanya apa, apakah tentang anti narkoba anti hoak atau apa tergantung momentya apa.tanggal berapa bulan apa. Dan posternya mereka kita tempel dimana-mana hasil lombaa itu nanti poster kita tempel di wilayah sekitar sekola, mbaknya tadi kan sudah keliling ada beberapa itu hasilnya mereka(IU,01)"

"waktu pelajaran di sosiologi kan sosiologi pernah ada permasalahn sosial seperti mengulas kenalakan remaja seperti penyalahgunaan narkoba dikaangan remaja, mereka bikin poster . nanti poster terbaik ditaruh mading seperti itu(IU,05)"

Tidak hanya melalui perlombaan, Kegiatan Pencegahan Narkoba juga dapat dilakukan melalui pembelajaran kelas dengan mata pelajaran yang terkait. Seperti Sosiologi, Pendidikan Agama dan Kewarganegaraan dengan berbagai metode pelajaran.

"..kalau narkoba lebih pada materi sosial, sosiologi, PKN Agama. Itu lebih pada sisi sosial dan spiritual kalau pelajaran yang lain hampir tidak tersentuh(IU,05)"

Hal ini juga disampaikan oleh siswa dengan keterangan sebagai berikut

"..kalo pelajaran olah raga kalo waktu jam materi itu kan biasanya kan olah raga kan ada materinya narkoba gitu kan, narkoba, seks bebas itu ada $(I K, 04) "$

Salah satu sekolah juga mengaitkan kegiatan pencegahan narkoba dalam pembelajaran kelas. Metode pembelajarannya berupa kegiatan penelitian yang dilakukan di pantai rehab. Hal ini juga disampaikan informan dengan keterangan sebagai berikut

"...dulu pernah sih waktu ngajar kelas 12 itu melakukan penelitian sosial. Anak-anak melakukan penelitian terhadap perilaku penyalahgunaan narkoba. Tu mereka datang ke panti rehabilitasi ke surya laya. Nah hasil dari penelitian sosial itu disemniarkan. Tapi seminarnya pun itu lebih pada intern sekolah(IU,05)"

Selain pemanfaatan guru BK, kegiatan bina suasana yang ditemukan adalah mengaitkan permasalahan narkoba dalam 
kegiatan belajar mengajar. Hal ini sesuai dengan penelitian sebelumnya yang menyatakan bahwa perlunya konsep Pembelajaran Kontekstual (Contextual Teaching and Learning-CTL) yaitu konsep belajar yang mendorong guru untuk menghubungkan antara materi yang diajarkan dengan situasi nyata siswa dan mendorong siswa membuat hubungan antara pengetahuan yang dimilikinya dan penerapannya dalam kehidupan mereka (Wahyudi, 2017).

Kegiatan perlombaan poster disaat pelajaran kelas yang dilakukan oleh Guru Sosiologi akan membuat siswa lebih memahami pesan perubahan sikap oleh pesan-pesan persuasif yang disampaikan. Sama halnya dengan penelitian yang dilakukan sebelumnya yang menyatakan bahwa melalui unsur dan desain komunikasi visual yang digabungkan dengan teori persuasif dalam kegiatan kampanye baik perlombaan ataupun sejenisnya, suatu media promosi kesehatan tersebut akan lebih sistematis dan efektif (Yuniati, 2014).

Untuk menciptakan kondisi siswa dari tau menjadi mau diperlukan adanya kondisi lingkungan yang mendukung. Berdasarkan model Precede Proceed Lawrence Green dijelaskan bahwa untuk mengubah suatu individu atau kelompok untuk mendapatkan kualitas hidup yang lebih baik dibutuhkan ilmu promosi kesehatan. Kegiatan pencegahan stunting yang dilakukan sesuai dengan penelitian yang dilakukan sebelumnya yaitu menggunakan media sebagai kegiatan pendukung promosi kesehatan (Sari dan Sulistyowati, 2015).

Hasil penelitian dalam pengembangan bina suasana yang dilakukan oleh peneliti lain yaitu untuk menciptakan lingkungan yang mendukung dalam pencegahan stunting menggunakan media seperti leaflet, Banner, Poster dan sejenisnya (Tiraihati, 2017).

Hasil Penelitian menunjukkan bahwa media promosi kesehatan seperti poster atau banner yang berada di lingungan sekolah tidak ditemukan. Padahal melalui media promosi, maka pesan-pesan yang disampaikan akan lebih mudah untuk dipahami sehingga masyarakat akan lebih mampu menangkap kegiatan apa yang sebaiknya mereka lakukan dan mana yang tidak. Pentingnya pemilihan media dalam melakukan promosi kesehatan sangatlah diperlukan dengan maksud mempermudah mencerna maksud dari media yang disampaikan tersebut (Yuniati, 2014).
Untuk itu kegiatan bina suasana yang dilakukan untuk menciptakan lingkungan yang mendukung lebih memperkuat pada aspek penyebaran informasi melalui media promosi kesehatan dianggap sangat efektif dalam model pembelajaran promosi kesehatan, supaya nanti ilmu yang tersampaikan akan mudah ditangkap dan diterima sesuai dengan maknanya (Haryati, 2018).

\section{KESIMPULAN DAN SARAN}

Kegiatan Bina Suasana yang dilakukan di sekolah menengah atas berdasarkan Strategi Promosi Kesehatan di kawasan Surabaya menunjukkan adanya kegiatan Konselor Sebaya, Sidak dan Tes Urin, Fasilitas BK dan Kegiatan Belajar Mengajar. Masing-masing dapat dijabarkan dengan keterangan sebagai berikut:

1. Kegiatan Konselor Sebaya yang sesuai dengan perwali nomor 65 tahun 2014 tentang rencana Aksi Pelaksanaan Kebijakan dan Strategi Daerah Bidang Pencegahan, Pemberantasan Penyalahgunaan dan Peredaran Gelap Narkoba Kota Surabaya Tahun 2014-2015 berupa adanya siswa siswi sekolah yang mewakili diri dalam kegiatan penyebaran edukasi kepada teman sebaya melalui sesi curhat. Posisi teman sebaya ini menggantikan BK.

2. Adanya sidak dan tes urin yang dilakukan kepolisian

3. Adanya Fasilitas Guru BK yang memiliki sikap terbuka dalam menerima keluh kesah siswa-siswinya serta tanggap dalam kegiatan pencegahan narkoba

4. Adanya kegiatan belajar mengajar yang mendukung. Seperti dalam pelajaran sosiologi, kewarganegaraan dan agama.

\section{DAFTAR RUJUKAN}

1] BNN. (2016) Hasil Survey Penyalahgunaan dan Peredaran Gelap Narkoba pada Kelompok Pelajar dan Mahasiswa di 18 Provinsi Tahun 2018.

2] BNN. (2017) Survey Nasional Penyalahgunaan Narkoba di 34 Provinsi Tahun 2017.

3] BPS. (2017) Kota Surabaya dalam Angka 2018.

4] Haryati. (2018) Pengaruh Influencer Marketing sebagai Pemasaran Digital Era Modern. Institut Informatika Indonesia. 
5] Kemenkes. (2011) Strategi Promosi Kesehatan di Daerah Bermasalah Kesehatan.

6] Kurniawan, Y., \& Sudrajat.Ajat. (2017) Peran Teman Sebaya dalam Pembentukan Karakter Siswa MTs. Jurnal Ilmu-Ilmu Sosial, 14(2).

7] Perwali Nomor 65 Tahun 2014 Tentang Rencana Aksi Pelaksanaan Kebijakan dan Strategi Daerah Bidang Pencegahan, Pemberantasan Penyalahgunaan dan Peredaran Gelap Narkoba Kota Surabaya Tahun 2014-2015

8] Rachmawati, A. I., Puspitasari, R. D., \& Cania, E. (2017) Faktor-faktor yang Memengaruhi Kunjungan Antenatal Care (ANC) Ibu Hamil. Majority Journal, 7(1).

9] Sari, I., \& Sulistyowati, M. (2015) Analisis Promosi Kesehatan Puskesmas Kalijudan Terhadap PHBS Rumah Tangga Ibu Hamil. Jurnal Promkes
10] Tiraihati, Z. W. (2017) Analisis Promosi Kesehatan Berdasarkan Ottawa Charter di RS Onkologi Surabaya. Jurnal Promkes, 5, $1-11$.

11] UNODC. 2017. World Drug Report 2017.

12] Wahyudi, A. (2017) Motif Perilaku Menyimpang Remaja dengan Kasus Penyalahgunaan Narkoba di Kota Surabaya. Paradigma, 01.

13] Yuniati, S. (2014) Implementasi Pendidikan Karakter dalam Pembelajaran dalam Matematika Melalui Pendekatan Kontekstual. Jurnal Al-Khwarizmi, II(1), 41-58.

14] Sari M., D. (2017) Peran Kader Penyalahgunaan Narkoba Berbasis Pelajar oleh Badan Narkotika Nasional Surabaya. Jurnal Promkes. 5, pp. 128-140.

15] Kurniawan, R. (2018) Strategi Promosi Kesehatan terhadap Upaya Penanggulangan Narkoba. MPPKI, 1(1), pp. 21-24. 